\title{
Gender Differences in Digital Competence Among Secondary School Students
}

\author{
https://doi.org/10.3991/ijim.v15i04.20197 \\ Siti Noorsuriani Maon ${ }^{\bowtie}$, Naffisah Mohd Hassan, Noorain Mohamad Yunus, \\ Sri Fatiany Abdul Kader Jailani, Erne Suzila Kassim \\ Universiti Teknologi MARA, Cawangan Selangor, Malaysia \\ sitinoor123@uitm.edu.my
}

\begin{abstract}
Digital technologies have become powerful tools in today society in many aspects. However, without proper knowledge and guidance, youth is being challenged with potential hazards of cybercrimes. Hence, the purpose of this study was to compare who is at a greater risk of cybercrimes, and to assess whether there is a significant difference in the digital competency between girls and boys at rural areas. Digital competence was measured as technology, cognitive, ethical knowledge and communication, and cybersecurity was measured as intellectual property, privacy, accuracy and accessibility. Questionnaires were distributed to selected secondary schools. Based on the t-test analyses of 211 responses, the findings indicate there is a significant difference in the attitude toward ICT usage between male and female students, as well as significant differences in the behaviour of troubleshooting, staying safe online and being credible and in the ethical knowledge. Comparing the cybersecurity traits, gender differentiates the privacy concerns, accuracy and accessibility behaviour. As the results are alarming, specific concerns and focus must be placed on youth digital technology usage and education for ensuring they are not neglected, and exposed as cyber victims, but also to raise a responsible e-society with excellent digital citizenship attributes.
\end{abstract}

Keywords-Digital Competency, ICT Usage in Rural Areas, Digital Citizen, Youth and Cybersecurity, Gender Differences in ICT

\section{$1 \quad$ Introduction}

In this century, the use of information and communication technology (ICT) has become a norm, whether for personal, social or official purposes. The rapid growth of ICT has been affected worldwide through various technologies, such as smartphones, tablets, mobile computers and many other digital devices. Moreover, the extensive usage of technology has influenced daily life activities including searching, processing, interacting, or producing information at work or for private purposes [1]. Having an ICT also leads to transforming countries from the industrial revolution towards the knowledge age, which it plays a vital role in generating and sustaining economic growth. In a knowledge society today, digital capability has developed into 
avital notion in deliberations on the types of essential skills and comprehension of learners.

Malaysia as a developing country is also focusing on digital competence in many areas including education. Nowadays, the use of digital technology is now predominant in many facets of instruction and learning. In the innovative educational landscape, many students need application of digital technologies to education and higher education requires these skills [2]. The improving of digital capability has become an essential component in producing of employable graduates [3]. Furthermore, students need to develop more than just their digital competency skills; they need to be conscious of the larger setting in which these skills and media function so students will be capable of using their skills efficiently and resourcefully in a growing digital world although assignation with digital competence has become a key element of pupils' daily life [4].

Since the start of the century with the advent of the Information and Data Society, there is a research that concentrate on the conceivable differences among male and female pupils in their usage of technology [5]. It is important to research on gender differences for secondary pupils' procurement of digital capability in helping to comprehend how male and female pupils interact with basic digital capabilities; it also has substantial educational and planned significances for the progress of these skills.

Hence, the objective of this research was mainly to examine the differences of digital capability and digital behaviour among secondary school pupils at rural areas in term of their gender.

\section{Literature Review}

Digital technologies have advanced more rapidly than any innovation in our history as the usage of digital technologies is being widely used by individuals in all settings. DTs are digital tools, systems, devices and resources that create, manage or storage of data. Some of the examples of digital technology are smartphones, websites, smart TV, digital music, computers, eBooks, social media, geo-locations and others. DTs have incorporated into people's daily life, from communications, finance to social interaction. In current years, there has been a rising number of literatures on digital competence. The context of DC has been introduced in 1990's. The definition of digital competence was first articulated as ability to perceive and utilize information in various forms from a wide range of sources when it is presented using computers. [6]. The definition of DC has broadened over the years. DC can be considered as basic skills in ICT. It can be defined as the use of computers to find, evaluate, store, produce, display and exchange information; and to communicate and engage in shared network via network [7]. A comprehensive definition of DC was suggested by [8]:

"A set of knowledge, skills and attitude that are required when using ICT and digital media to perform tasks, solve problems, communicate, manage information, collaborate, create and share contents, build knowledge effectively, appropriately critically, creatively, autonomously, flexibly, ethically, reflectively for work, leisure, participation, learning, socializing, consuming, and empowerment”. 
In view of all the definition, DC encompasses more than understanding how to use devices and applications. It is about sensible and healthy use of ICT that requires precise knowledge and attitudes concerning legal and righteous aspects, privacy and security [8]. The development of DC is seen as important aspects in education. According to Calvani, Fini and Ranieri [9], DC comprised of technological, cognitive and ethical dimensions. Technological dimension can be described as abilities to explore and face challenges; and new high-technology contexts in a flexible way, the cognitive dimensions make mention of being able to read, select, explain and assess data and information taking into their relevance and reliability and ethical knowledge refers to abilities to respect others and having sense of responsibility when using available DTs [10]. The technological dimension categorized into visual literacy, understanding technological concepts and troubleshooting to solve common technological problems [9]. The cognitive dimension comprised of cognitive skills; including organising and connecting textual and visual data, organising structured data and searching information is skills evaluating information critical [11]. The ethical dimension can be described as the ability to engage appropriately with others, including hold personal privacy and having acceptable knowledge of social and emotional literacy [11].

In Malaysia, the quantity of web clients in the nation has now surpassed 20 million, with 16.8 million being via web-based networking media [12]. The appropriation rate among Internet clients was diminishing as the age climbs. As far as Internet experience, $31.9 \%$ of Internet clients were associated as ahead of schedule as five years of age. Almost $80 \%$ of web clients were from the $19-49$ age, while $20 \%$ of the $55-74$ age bunches had scarcely utilized the Internet. The measurements demonstrated underline that there is a need to guarantee that all individuals have the open door from right off the bat in their training to see the estimation of computerized apparatuses and media and obtain the aptitudes to utilize the DTs. In addition, the insights show that there is have to create learning open doors for individuals who have just gotten done with formal instruction, yet they need DC to partake in the public eye and for their work and individual living. Notwithstanding that, guardians need a comprehension of DC to secure, bolster and teach their small kids in day-by-day advanced use. Recent information shows that $77 \%$ of $13-16$ years of age youngsters and $38 \%$ of $9-12$ years of age kids in Europe have utilized long-range interpersonal communication locales, anyway about every one of them are uninformed of the security settings. An investigation led in Malaysia found that female students are more mindful and have positive bits of knowledge than male, the age gathering of 18-23 years students have a lower recognition and mindfulness contrasted with those students who matured 24 years or more. Moreover, student who were having higher scholastic capabilities had progressively mindful at cybercrime and seen the issue of hazard in an alternate manner [13]. There are four huge advanced issues had been featured in a hypothetical social structure;including protected innovation, precision, security and availability [14, 15]. These noteworthy computerized issues have impacted disposition; thusly influences conduct aim, and social expectation, thusly influences genuine conduct [16]. The investigation found that protected innovation and precision affected demeanor towards web use, and furthermore impacted the expectation to utilize and genuine web 
conduct [16]. As indicated by Kavuk et al. [17], the illicit web conduct is usually not socially acknowledged may prompt dishonest web practices. A few instances of the unscrupulous practices are replicating programming without authorization, dispersion of data without assent, sending spam, and access inadmissible virtual condition like erotic entertainment condition. Because of that, it is unequivocally recommended that instructors are deprived to be able on the best way to teach computerized obligations so as to give moral in advanced establishment to students [18]. Subsequently, the students must be skilled in utilizing DTs. Be that as it may, those yet to be associated stay cut off from the advantages of DTs and stay further behind.

\section{Methodology}

\subsection{Population, sample size and data collection}

Population of the study was school children at rural areas. In order to identify the sample, two methods were used. First, is the identification of the rural schools. The method was established by clustering them in accordance to the region. Four regions were identified, which are the north, east, south and west. Next, is the identification of schools that represent each region. The school selection was made by referring to the school list from the Ministry of Education. At least three schools were randomly selected for each region, and application for the ethical procedure for data collection was submitted to the ministry and the District Department of Education. Upon approval, only three schools were made possible for their learners to participate in the study. The next step of the sample selection was determining the learners as the potential respondents. As there are regulations on the learners' participation in any research activities, the decision was made by the school administration. The requirements of respondents' characteristics such as the number of male and female learners, and the common family background as to avoid profile biasness were then forwarded to the school administration. Finally, based on the purposive sampling technique, a total of 240 samples were obtained from all schools that have been determined. The data was collected by grouping the sample into smaller groups. They were then couched on how to answer, and guideline on how to answer each question was provided. Careful assistance was given to ensure all of the respondents had a very clear understanding of the meaning of each item.

\subsection{Instrument design}

An instrument survey was used to gather data and survey question was divided into three sections; including the demographics and pattern of digital usage was sought in section one; the second section of the survey instrument measures DC and cybersecurity. In this study, DC was measured as a second order model with the constructs of technology, cognitive, ethical knowledge and communication. The technological construct was further measured as visual literacy, troubleshooting and understanding technical concepts. Cognitive was measured by organizing and structuring data; and 
information research. Keeping aware of safety and respect, others via online constructs were used to measure the ethical knowledge. These survey questions of DC used a 5-point Likert scale (from 1 - very unskillful to 5 - very skillful). Cybersecurity was measured as intellectual property, privacy, accuracy and accessibility. These survey items were measured using a 5-point Likert Scale (from 1 - strongly disagree to 5 - strongly agree). The final section focused on frequency of digital behaviour. These items measurement was based on frequency in nature (from 1 - never to 5 always). These items were selected from previous research and subsequently modified to fit the cyber-ethics issues and digital behaviour and belief. Statistical package for social science software (IBM SPSS version 23.0) was used to analysed all the obtained data. Both descriptive and inferential statistics were applied. Simple frequencies were performed to study characteristics of the respondents. Comparison analysis was carried out to examine differences in the DC and behaviour between genders.

\section{$4 \quad$ Results and Discussion}

Descriptive analysis is presented in this section. Demographic background of respondents will be described. Frequency and percentage of data obtained will be presented. In describing comparison analysis findings, Cohen's d criterion benchmark for small $(r=0.20)$, medium $(r=0.50)$, and large $(r=0.80)$ effect sizes will used in order to help interpret the relative size of the difference magnitudes [19].

\subsection{Demographic profile}

The respondents' demographic characteristics include gender, school levels and digital usage. In total, 211 were valid for data analysis; including female learners represent $54 \%$ of the respondents $(n=114)$ and male learners represent $46 \%(n=97)$. The findings indicated that $60 \%$ of learners were from lower level $(n=128)$ and upper level represent $39.3 \%(n=83)$. Approximately $40 \%$ of learners had been starting using computer since 2 to 5 years ago.

More than half of the learners $(n=140)$ have internet access at home, but only $34 \%$ $(n=71)$ of learners have computer at home. Majority of the respondents used smartphone $(n=180,85 \%)$ and half of the respondents spent several times a day using internet $(n=109,51.7 \%)$. Nearly $60 \%$ of the learners used Word application, however it was reported that no more than $50 \%$ of the learners use computer and internet access to do school assignments occasionally. Details of demographic characteristics between genders are shown in Table 1. 
Table 1. Demographic characteristics between genders $(\mathrm{N}=211)$

\begin{tabular}{|c|c|c|c|c|c|c|}
\hline \multicolumn{2}{|l|}{ Variable } & \multicolumn{2}{|c|}{$\begin{array}{c}\text { Male } \\
(n=97,46 \%)\end{array}$} & \multicolumn{2}{|c|}{$\begin{array}{c}\text { Female } \\
(n=114,54 \%)\end{array}$} & \multirow[t]{2}{*}{ Total } \\
\hline & & $n$ & $\%$ & $n$ & $\%$ & \\
\hline \multirow{2}{*}{ Form } & Lower & 60 & 61.9 & 68 & 59.6 & $128(60.7 \%)$ \\
\hline & Upper & 37 & 38.1 & 46 & 40.4 & $83(39.3 \%)$ \\
\hline \multirow{4}{*}{ Start using computer } & $<1$ year & 23 & 23.7 & 16 & 14.0 & $39(18.4 \%)$ \\
\hline & $2-5$ years & 33 & 34.0 & 44 & 38.6 & $78(36.8 \%)$ \\
\hline & $6-10$ years & 31 & 32.0 & 31 & 27.2 & $62(29.4 \%)$ \\
\hline & $11-15$ years & 10 & 10.3 & 23 & 20.2 & $33(15.6 \%)$ \\
\hline \multirow{2}{*}{ Having computer at home } & Yes & 29 & 29.9 & 42 & 36.8 & $71(33.6 \%)$ \\
\hline & No & 68 & 70.1 & 72 & 63.2 & $140(66.4 \%)$ \\
\hline \multirow{2}{*}{ Having internet access at home } & Yes & 49 & 50.5 & 75 & 65.8 & $124(58.8 \%)$ \\
\hline & No & 48 & 49.5 & 39 & 34.2 & $87(41.2 \%)$ \\
\hline \multirow{4}{*}{ Time spent accessing internet } & Several times a day & 53 & 54.6 & 56 & 49.1 & $109(51.7 \%)$ \\
\hline & Once a day & 20 & 20.6 & 25 & 21.9 & $45(21.3 \%)$ \\
\hline & Several times a week & 13 & 13.4 & 15 & 13.2 & $28(13.3 \%)$ \\
\hline & Once a week & 11 & 11.4 & 18 & 15.8 & $29(13.8 \%)$ \\
\hline \multirow{4}{*}{ Digital device use } & Desktop & 15 & 15.5 & 2 & 1.8 & $17(8.1 \%)$ \\
\hline & Laptop & 4 & 4.1 & 6 & 5.3 & $10(4.7 \%)$ \\
\hline & Tablet & 2 & 2.1 & 2 & 1.8 & $4(1.9 \%)$ \\
\hline & Smartphone & 76 & 78.4 & 104 & 91.2 & $180(85.3 \%)$ \\
\hline \multirow{5}{*}{$\begin{array}{l}\text { Use computer to do school as- } \\
\text { signment }\end{array}$} & Always & 3 & 3.1 & 6 & 5.3 & $9(4.3 \%)$ \\
\hline & Very often & 8 & 8.2 & 10 & 8.8 & $18(8.5 \%)$ \\
\hline & Sometimes & 44 & 45.4 & 47 & 41.9 & $91(43.1 \%)$ \\
\hline & Rarely & 37 & 38.1 & 45 & 39.3 & $82(38.9 \%)$ \\
\hline & Never & 5 & 5.2 & 6 & 5.3 & $11(5.2 \%)$ \\
\hline \multirow{5}{*}{$\begin{array}{l}\text { Use Internet to do school assign- } \\
\text { ment }\end{array}$} & Always & 4 & 4.1 & 9 & 7.9 & $13(6.2 \%)$ \\
\hline & Very often & 14 & 14.4 & 23 & 20.2 & $37(17.5 \%)$ \\
\hline & Sometimes & 44 & 45.4 & 60 & 52.6 & $104(49.3 \%)$ \\
\hline & Rarely & 30 & 30.9 & 19 & 16.7 & $49(23.2 \%)$ \\
\hline & Never & 5 & 5.2 & 3 & 2.6 & $8(3.8 \%)$ \\
\hline \multirow{5}{*}{ Computer application used } & Word & 54 & 55.7 & 70 & 61.4 & $124(58.8 \%)$ \\
\hline & Presentation & 19 & 19.6 & 31 & 27.2 & $50(23.7 \%)$ \\
\hline & Spreadsheet & 3 & 3.1 & 1 & 0.9 & $4(1.9 \%)$ \\
\hline & Graphics & 16 & 16.5 & 7 & 6.1 & $23(10.9 \%)$ \\
\hline & Others & 5 & 5.2 & 5 & 4.4 & $10(4.7 \%)$ \\
\hline
\end{tabular}

\subsection{Access to usage of internet}

In terms of the Internet usage, respondents were asked two items namely "how do they get connected to Internet?" and "what are digital activities they did?" These items were multi-responses. As seen on Table 2, home $(n=146,38 \%)$ and school $(\mathrm{n}=85,22 \%)$ were the common places that the learners had the Internet connection. Nearly half of female learners get connected to Internet at home $(n=90,45 \%)$. Table 2 describes digital activities and how getting internet connection between male and female learners. 
Table 2. Getting Internet Connection and digital activities $(\mathrm{N}=211)$

\begin{tabular}{|c|c|c|c|c|c|c|}
\hline \multirow{2}{*}{\multicolumn{2}{|c|}{ Variable }} & \multicolumn{2}{|c|}{ Male } & \multicolumn{2}{|c|}{ Female } & \multirow{2}{*}{ Total } \\
\hline & & $n$ & $\%$ & $n$ & $\%$ & \\
\hline \multirow{5}{*}{$\begin{array}{l}\text { Connecting to } \\
\text { Internet }\end{array}$} & Home & 56 & 30.1 & 90 & 45.0 & $146(37.8 \%)$ \\
\hline & Friend's or relative house & 30 & 16.1 & 35 & 17.5 & $65(16.8 \%)$ \\
\hline & Cybercafé & 38 & 20.4 & 8 & 4.0 & $46(11.9 \%)$ \\
\hline & Other eateries & 28 & 15.1 & 16 & 8.0 & $44(11.4 \%)$ \\
\hline & School & 31 & 16.7 & 43 & 21.5 & $85(22 \%)$ \\
\hline \multirow{11}{*}{$\begin{array}{l}\text { Digital activi- } \\
\text { ties }\end{array}$} & Play online games & 87 & 17.8 & 47 & 7.3 & $134(63.0 \%)$ \\
\hline & Social media and networking & 60 & 12.2 & 83 & 12.9 & $143(67.3 \%)$ \\
\hline & Email & 7 & 1.4 & 7 & 1.1 & $14(6.6 \%)$ \\
\hline & Media sharing and internet searching & 23 & 4.7 & 47 & 7.4 & $70(33.2 \%)$ \\
\hline & Smartphone usage & 54 & 11.0 & 70 & 11 & $124(58.8 \%)$ \\
\hline & Pictures and Video recording & 45 & 9.2 & 63 & 9.9 & $108(51.2 \%)$ \\
\hline & Information searching & 38 & 7.8 & 57 & 9.0 & $95(45.0 \%)$ \\
\hline & TV and movie viewing & 43 & 8.8 & 58 & 9.1 & $101(47.9 \%)$ \\
\hline & Online friendship & 49 & 10.0 & 71 & 10.9 & $118(55.9 \%)$ \\
\hline & Work with learning software & 21 & 4.3 & 44 & 6.9 & $65(30.8 \%)$ \\
\hline & Listen to music & 63 & 12.9 & 92 & 14.4 & $154(73 \%)$ \\
\hline
\end{tabular}

In view of digital activities, the most three common digital activities among the learners were listening to music $(n=154,73 \%)$, visiting social media and networking $(n=143,67.3 \%)$ and playing online games $(n=134,63 \%)$. Female learners are more listening to music $(n=92,14.4)$ and participating in social media and networking $(n=83,12.9)$, whereas male learners more interested in playing online games $(n=87$, $17.8 \%)$. On the other hand, the least three digital activities were using email $(n=14$, $6.6 \%)$, work with learning software $(n=65,30.8 \%)$ and media sharing $(n=70,33.2 \%)$. A study conducted in primary schools were also found that playing online games, surf the websites, participating in chatting with friends through social networking sites were significant digital activities among the school learners who above aged of 10 [16].

\subsection{Differences in the mean values}

The t-test analysis revealed no significance differences were found in the visual literacy, understanding technical concepts, organizing data, information research, and communication and respect others between male and female learners. However, there was a significantly difference in troubleshooting $(\mathrm{t}(209)=3.057 ; \mathrm{p}=0.002 ; \mathrm{d}=$ $0.43)$.and stay safe online $(\mathrm{t}(209)=-2.871 ; \mathrm{p}=0.005 ; \mathrm{d}=0.39$. These results indicate that the mean total score for male learners $(M=2.50 ; S D=0.968)$ was much higher compared to female learners $(\mathrm{M}=2.11 ; \mathrm{SD}=0.823)$ in troubleshooting. 
Table 3. DC Dimensions and Each Construct

\begin{tabular}{|c|c|c|c|c|c|c|c|}
\hline Variables & Male & Female & \multirow{2}{*}{$\mathbf{t}$} & \multirow{2}{*}{$\mathbf{p}$} & \multirow{2}{*}{$\begin{array}{c}\text { Mean } \\
\text { Difference }\end{array}$} & \multicolumn{2}{|c|}{ Confidence Interval } \\
\hline Construct & $M(S D)$ & $M(S D)$ & & & & Lower & Upper \\
\hline Visual literacy & $3.141(0.826)$ & $3.243(0.824)$ & -0.871 & 0.385 & -0.102 & -0.332 & 0.128 \\
\hline Troubleshooting & $2.502(0.968)$ & $2.119(0.823)$ & 3.057 & 0.002 & 0.382 & 0.135 & 0.628 \\
\hline Technical Concept & $3.575(0.937)$ & $3.623(0.813)$ & -0.390 & 0.697 & -0.475 & -0.288 & 0.193 \\
\hline $\begin{array}{l}\text { Organizing and } \\
\text { Structuring Data }\end{array}$ & $2.534(0.801)$ & $2.521(0.774)$ & 0.119 & 0.905 & 0.129 & -0.201 & 0.227 \\
\hline Information research & $3.148(0.709)$ & $3.266(0.728)$ & -1.191 & 0.235 & -0.118 & 0.314 & 0.776 \\
\hline Respect others & $3.639(0.734)$ & $3.813(0.674)$ & -1.791 & 0.075 & -0.174 & -0.365 & 0.017 \\
\hline Stay safe online & $3.333(1.082)$ & $3.739(0.973)$ & -2.871 & 0.005 & -0.406 & -0.685 & -0.127 \\
\hline DIMENSION & & & & & & & \\
\hline Technological & $3.164(0.718)$ & $3.109(0.624)$ & 0.593 & 0.554 & 0.054 & -0.127 & 0.237 \\
\hline Cognitive & $2.534(0.800)$ & $2.521(0.774)$ & 0.119 & 0.905 & 0.013 & -0.201 & 0.227 \\
\hline Communication & $3.019(0.695)$ & $3.117(0.629)$ & -1.070 & 0.286 & -0.097 & -0.277 & 0.822 \\
\hline Ethical Knowledge & $3.486(0.804)$ & $3.776(0.673)$ & -2.812 & 0.005 & -0.290 & -0.490 & -0.896 \\
\hline
\end{tabular}

In contrast, the mean total score for male learners $(\mathrm{M}=3.33$; $\mathrm{SD}=1.082)$ was much lower compared to female learners $(\mathrm{M}=3.74 ; \mathrm{SD}=0.97)$. The effect size for both troubleshooting $(d=0.432)$ and stay safe online $(d=0.391)$ were found to exceed Cohen's $(1988)$ convention for a small effect $(d=.20)$. Details are shown in Table 3. These study findings in line with a study conducted by He \& Zhu [11] that found significant differences between female and male learners in terms of trouble shooting and organizing and connecting textual and visual data, however, the other sub-scales of DC of visual literacy, understanding technical concept, information searching, respects to others and stay safe online were found no differences between female and male learners.

Overall, the study findings indicate that no significant difference in technological, cognitive and communication dimensions of DC between male and female learners. However, ethical knowledge dimension was found significant difference between gender $(\mathrm{t}(209)=-2.812 ; \mathrm{p}=0.005 ; \mathrm{d}=0.391)$. The total of mean score for female learners $(\mathrm{M}=3.78 ; \mathrm{SD}=0.67)$ was much higher compared to male learners $(\mathrm{M}=3.47$; $\mathrm{SD}=0.80)$. The effect size for this analysis $(\mathrm{d}=0.39)$ was found to exceed Cohen's (1988) convention for a small effect $(d=.20)$.

Table 4. Digital behaviour and cybersecurity constructs

\begin{tabular}{|l|c|c|c|c|c|c|c|}
\hline \multirow{2}{*}{ Variables } & Male & \multirow{2}{*}{ Female } & \multirow{2}{*}{$\mathbf{t}$} & \multirow{2}{*}{$\mathbf{p}$} & $\begin{array}{c}\text { Mean } \\
\text { Difference }\end{array}$ & \multicolumn{2}{c|}{$\begin{array}{c}\text { Confidence } \\
\text { Interval }\end{array}$} \\
\cline { 2 - 3 } & $\boldsymbol{M}(\boldsymbol{S D})$ & $\boldsymbol{M}(\boldsymbol{S D})$ & & & & Lower & Upper \\
\cline { 2 - 5 } & $3.241(0.768)$ & $3.142(0.731)$ & 0.959 & 0.339 & 0.099 & -0.105 & 0.303 \\
\hline Intellectual Property & $3.688(1.147)$ & $4.108(1.079)$ & -2.871 & 0.005 & -0.441 & -0.743 & -0.138 \\
\hline Privacy & $3.284(0.689)$ & $3.600(0.607)$ & -3.531 & 0.001 & -0.315 & -0.491 & -0.139 \\
\hline Accuracy & $2.924(0.823)$ & $3.207(0.876)$ & -2.406 & 0.017 & -0.283 & -0.515 & -0.051 \\
\hline Accessibility & $1.727(0.489)$ & $1.375(0.337)$ & 6.047 & 0.000 & 0.352 & 0.237 & 0.467 \\
\hline Digital behaviour (computer) & $1.529(0.383)$ & $1.304(0.265)$ & 4.878 & 0.000 & 0.225 & 0.134 & 0.316 \\
\hline Digital behaviour (internet) & 1.525 & & & &
\end{tabular}


As shown in Table 4, the study results revealed significance difference in privacy ( $\mathrm{t}$ $(209)=-2.871 ; \mathrm{p}=0.005 ; \mathrm{d}=0.377)$, accuracy $(\mathrm{t}(209)=-3.531 ; \mathrm{p}=0.001 ; \mathrm{d}=0.487)$ and accessibility $(\mathrm{t}(209)=-2.406 ; \mathrm{p}=0.017 ; \mathrm{d}=0.332)$ constructs between male and female learners. It is indicated that the total mean score for female learners were much higher than male learners in privacy, accuracy and accessibility. The findings revealed that effects for the privacy $(\mathrm{d}=0.377)$ and accessibility $(\mathrm{d}=0.332)$ levels are small, but accuracy level $(\mathrm{d}=0.487)$ is fairly medium. The findings found that there was a statistically significant difference between male and female learners, in terms of digital behaviour for both computer $(\mathrm{t}(209)=6.047 ; \mathrm{p}<0.001 ; \mathrm{d}=0.838)$ and internet $(\mathrm{t}$ $(209)=4.878 ; \mathrm{p}<0.001 ; \mathrm{d}=0.683)$. Male learners were more slightly rare doing unethical digital behaviour related to computer $(\mathrm{M}=1.73 ; \mathrm{SD}=0.49)$ and internet activities $(\mathrm{M}=1.53 ; \mathrm{SD}=0.38)$ compared to female learners. The mean score for female learners reported that they never involve in any unethical digital behaviour relating to both computer $(\mathrm{M}=1.37 ; \mathrm{SD}=0.34)$ and internet $(\mathrm{M}=1.30 ; \mathrm{SD}=0.26)$. The findings revealed that the effect size for digital behaviour related to computer $(\mathrm{d}=0.838)$ was found to exceed Cohen's (1988) convention for a large effect $(d=.80)$ and internet $(d=0.683)$ was considered as fairly large. In contrast, Li \& Ranieri [20] found that the performance of learners who were aged between 14 to 17 , in DCs including technological, cognitive and ethical knowledge dimension did not differ by gender and these learners' performance in DC also did not differ by such factors as having a personal computer or not, having the Internet or not at home, frequency of computers or Internet usage. However, the learners' performance in DC were found differed by age categories; in which the younger the learners were, the better their performance in the DC [20].

\section{Conclusion}

Overall, there was no significant difference in technological, cognitive and communication dimension between genders. However, findings revealed that ethical knowledge has significant difference between male and female learners. Female learners more aware towards ethical knowledge especially in terms of their privacy, accuracy and accessibility when they are using digital technology and the Internet as compared to male learners. We believe that female learners are taking precaution and taking effort to take measures to secure their safety in digital environment. However, we still see a need for research that determines their underlying causes why these happens. These findings can assist educators finding strategies to enhance and integrate learners' digital literacy and competence into education in becoming a good digital citizen. Instilling digital citizenship skills through education is crucial to helping learners be confident to ensure preventing unacceptable digital moral values such as cyberbully, online unsafety, digital irresponsibility, and privacy issues. One of limitations of this study is the target population where researcher only focus on rural secondary school learners; including both lower and upper forms. This is due to time and resource limitation to complete the study. For future research, it is suggested that population will be selected from all geographical area including urban and sub-urban 
area. This is to ensure that the findings represent a nationwide school learners' digital competency.

\section{Acknowledgement}

We would like to express our sincere gratitude to Universiti Teknologi MARA, (UiTM) Shah Alam and the Faculty of Business and Management, Universiti Teknologi MARA (UiTM) Cawangan Selangor, Kampus Puncak Alam, for their kind support and contributions. This research was funded by Universiti Teknologi MARA for funding the study via BESTARI Perdana Grant; 600-IRMI/DANA5/3/BESTARI (P) $(032 / 2018)$.

\section{$7 \quad$ References}

[1] Hatlevik OE, Gudmundsdóttir GB, Loi M., "Examining factors predicting students' digital competence", J. Inf Technol Educ, 2015;

[2] Gallardo Echenique EE, Marqués Molías L, Bullen M., "Students in higher education: Social and academic uses of digital technology", RUSC Univ Knowl Soc J, 2015 https://doi.org/10.7238/rusc.v12i1.2078

[3] Qureshi MI, Khan N, Gillani SM, Raza H. "A Systematic Review of Past Decade of Mobile Learning: What we Learned and Where to Go.", International Journal of Interactive Mobile Technologies (iJIM),2020 Apr 17;14(06):67-81. https://doi.org/10.3991 lijim.v14i06.13479

[4] Shariman TPNT, Talib O, Ibrahim N., "The relevancy of digital literacy for malaysian students for learning with WEB 2.0 technology", In: Proceedings of the European Conference on e-Learning, ECEL, 2014.

[5] Vázquez-Cano E, Meneses EL, García-Garzón E., "Differences in basic digital competences between male and female university students of Social Sciences in Spain", Int J Educ Tech-nol High Educ, 2017 https://doi.org/10.1186/s41239-017-0065-y

[6] Gilster P, Watson T., "An Excerpt from Digital Literacy", Digit Lit, 1997

[7] European Council, "Recommendation of the European Parliament and the Council on key competencies for lifelong learning", Off J Eur Union, 2006

[8] Ferrari A, Punie Y, Redecker C., "Understanding Digital Competence in the 21st Century: An Analysis of Current Frameworks", In 2012 https://doi.org/10.1007/978-3-642-33263$\underline{0 \_7}$

[9] Calvani A, Calvani A, Fini A, Ranieri M., "Assessing the digital competence. Theoretical models and application tools", Ital J Educ Technol, 2009

[10] Khan N, Qureshi M. "A systematic literature review on online medical services in Malaysia."

[11] He T, Zhu C., "Digital informal learning among Chinese university students: the effects of digital competence and personal factors", Int J Educ Technol High Educ, 2017 https://doi.org/10.1186/s41239-017-0082-x

[12] MCMC Survey, "Internet Users Survey 2017 - statistical brief number twenty-one", Malayasian Commun Multimed Comm, 2017 
[13] Hasan MS, Rahman RA, Abdillah SFHBT, Omar N., "Perception and Awareness of Young Internet Users towards Cybercrime: Evidence from Malaysia", J Soc Sci, 2015 https://doi.org/10.3844/jssp.2015.395.404

[14] Mason RO., "Four ethical issues of the information age", MIS Q Manag Inf Syst, 1986 https://doi.org/10.2307/248873

[15] T Selwyn Ellis, Griffith D., "The evaluation of IT ethical scenarios using a multidimensional scale", Database Adv Inf Syst, 2001

[16] Masrom M, Hasnaa N, Mahmood N, Zainon O., "Cyberethics and Internet Behaviour of Malaysian Primary Education Students", J. Emerg Trends Educ Res Policy Stud, 2013

[17] Kavuk M, Keser H, Teker N., "Reviewing unethical behaviors of primary education students' internet usage", In: Procedia - Social and Behavioral Sciences, 2011 https://doi.org/10.1016/j.sbspro.2011.11.190

[18] Khan N, Qureshi M, Mustapha I, Irum S, Arshad R. "A systematic literature review paper on online medical mobile applications in Malaysia."

[19] Cohen J., "Statistical Power Analysis for the Behavioural Science", (2nd Edition). In: Statis-tical Power Anaylsis for the Behavioral Sciences, 1988

[20] Li Y, Ranieri M., "Are digital natives really digitally competent? -A study on Chinese teen-agers", Br. J. Educ Techno, 2010 https://doi.org/10.1111/j.1467-8535.2009.01053.x

\section{Authors}

Siti Noorsuriani Maon is an associate professor in the Department of International Business and Management Studies, Faculty of Business and Management at Universiti Teknologi MARA (UiTM), Cawangan Selangor, Kampus Puncak Alam, Malaysia. She is actively participated in several research works and community projects relevant to her interest. She is the recipient of several research grants; including internal and national grants. Her research interest includes management, health behavior, health informatics and technological intervention in health improvement.

Naffisah Mohd Hassan is a senior lecture in the Department of International Business and Management Studies for Faculty of Business and Management at Universiti Teknologi MARA (UiTM), Cawangan Selangor, Kampus Puncak Alam, Malaysia. She received her $\mathrm{PhD}$ from University of Wollonggong, Australia. She is an active member of community engagement projects with NGOs. She has organized a number of community projects to raise awareness, understanding and acceptance of autism within Muslim communities.

Noorain Mohamad Yunus is a senior lecturer the Department of International Business and Management Studies, Faculty of Business and Management at Universiti Teknologi MARA (UiTM), Cawangan Selangor, Kampus Puncak Alam, Malaysia. She received her PhD from International Islamic University Malaysia (IIUM). Currently, she has been appointed as Head of Department at faculty. She has published papers in several journals and conference papers. She is the recipient of several research grants; including internal and national grants.

Sri Fatiany Abdul Kader Jailani is a senior lecturer in the Department of Technology and Supply Chain Management Studies, Faculty of Business and Management at Universiti Teknologi MARA (UiTM), Cawangan Selangor, Kampus Puncak Alam, Malaysia. She received her $\mathrm{PhD}$ from International Islamic University Malaysia 
(IIUM). She received a bachelor's degree and a master's degree in Information Technology from Universiti Teknologi MARA Malaysia. Her current field placement is with the Universiti Teknologi MARA. Her research area including information technology, sustainability and social networking.

Erne Suzila Kassim is an associate professor in the Department of Technology and Supply Chain Management Studies, Faculty of Business and Management at Universiti Teknologi MARA (UiTM), Cawangan Selangor, Kampus Puncak Alam, Malaysia. Erne received her Bachelor Degree from Indiana University in Bloomington, USA, majoring in Economics and Sociology, MSc and PhD in IT, mainly specializing in digital innovations. She has been awarded with research grants for projects in e-learning, green IT, e-commerce and IT for micro-enterprises. Her research interests include social networking, social innovation and value creation.

Article submitted 2020-12-02. Resubmitted 2021-01-03. Final acceptance 2021-01-10. Final version published as submitted by the authors. 